\title{
The Twin Cities-Minneapolis and St. Paul
}

\section{Earl Dow Brown}

To cite this article: Earl Dow Brown (1922) The Twin Cities-Minneapolis and St. Paul, Journal of Geography, 21:6, 227-232, DOI: 10.1080/00221342208984157

To link to this article: http://dx.doi.org/10.1080/00221342208984157

曲 Published online: 13 Feb 2008.

Submit your article to this journal $\widetilde{ }$

Џ Article views: 3

Q View related articles $₫$ 
printing, wood products. The most striking condition in manufacturing is the lack of specialization, due, doubtless, in a great measure to the diversified character of the tributary market area, including as it does not only a fertile farming region, but many flourishing towns and mining centers as well; and to the fact that the city now possesses no special advantage in securing any one particular class of raw materials, but is fairly well located with respect to many. Chicago forged ahead in meat-packing in 1860, Cleveland and other more northern cities have a superior location for iron and steel manufacture, and the hard wood forests of the Appalachain plateau, once a valuable asset, are disappearing. By the census of 1920 Cincinnati ranked thirteenth among the cities of the United States with respect to the number of persons employed in manufacturing; and fourteenth with respect to the value of the products of manufacture.

\section{BIBLIOGRAPHY}

1. N. M. Fenneman, Geology of Cincinnati and Vicinity, Geological Survey of Ohio. Fourth Series, Bulletin 19.

2. N. M. Fenneman, Site of Cincinnati, Jour. of Geog. Vol. 14, pp. 10-12.

3. I. R. Garbutt, Development of Cincinnati, Jour. of Geog. Vol. 9, pp. 182-183.

4. Salisbury, Barrows, and Tower, Elements of Geography, pp. 586-601.

\section{THE TWIN CITIES-MINNEAPOLIS AND ST. PAUL}

\section{EARL DOW BROWN}

In 1679 Father Hennipin, the intrepid priest-explorer, ascended the Mississippi and stopped at the falls of St. Anthony, which he named after his patron, St. Anthony of Padua. A few years later some French traders, looking for furs, paddled up the river to the foot of the falls just above St. Paul. This part of the country was rich in furs brought down the rivers from the North. Here a trading post was established and trade began with the Indians.

In 1805, the building of Fort Snelling seems to mark the starting point for the real growth of the Twin Cities. Minneapolis and St. Paul were situated at very advantageous positions, Minneapolis being at the southern point for boats coming down the river and also at the falls, and St. Paul being at the northern point for boats going up the river.

The upper Mississippi flowed thru a region thickly forested and capable of furnishing millions of feet of lumber which could be floated down the rivers to the source of power at St. Anthony Falls. Every spring the rivers were fairly choked with logs.

St. Paul had been named the territorial capital, and the government had been administered from this city with very little friction, but in 1848 when plans were being made for the location of the state capital, Minneapolis and Stillwater put in their demands; a compromise was effected which gave to St. Paul the capital, to Minneapolis the university, and to Stillwater the state 
prison. Minneapolis became a milling city. The water power turned the wheels of both the saw mills and flour mills, and the river furnished the high way for $\log$ and lumber transportation. On the other hand, St. Paul was located a little farther south on the river at the terminus of transportation coming up the river, and it became a distributing center for goods going to the Northwest, and later a manufacturing and marketing center for the dairy products of Minnesota.

\section{The Influence of the Surrounding Territory on the Growth of The Twin Cities}

The growth of a western city is so closely related to the resources and conditions of its surroundings that it would not be wise to separate the city from the territory of which it is a center.

The development and growth of the Twin Cities run parallel with the development of Minnesota, North and South Dakota, southern Canada, and northern Wisconsin; and it is very natural that these cities should reflect the prosperity of this fertile region. Minnesota had its forests, the Dakotas have their fertile areas of wheat land, and the rivers rising in Wisconsin and Minnesota are capable of furnishing abundant power.

\section{MinNeApolis}

The Influence of Lumber. After Minneapolis had become a small village, and the fur trade had furnished the few people with a means of livlihood, the lumber industry began its remarkable growth. The camps increased rapidly and the profits from previous years furnished capital for still larger enterprises. In 1848, 1,500,000 feet of lumber were cut; in 1851, 9,000,000 feet, and by 1857 the production had reached $45,000,000$ feet. Logs were even used as money. The merchants supplied the logging companies with food, clothing, and tools, and in payment often accepted logs. The lumber industry was highly profitable, and there was a market for all the lumber that could be cut. The price ranged from $\$ 10.00$ to $\$ 16.00$ per thousand feet. Labor was cheap, and food was plentiful. The result was that profits were piled up, and the capital was invested later in the new manufacturing establishments.

Down to 1843 the lumber industry had been purely local, and the markets were local. Most of the lumber was used in Minneapolis, St. Paul, and Stillwater, in the building of the houses for settlers who were swarming into the settlements, and for the building of mills, booms, and stores. In 1843 an accident occured which influenced the growth of the lumber market. The boom at Stillwater, which held several million feet of lumber, went out, and the logs were scattered along the Mississippi River as far south as St. Louis. The logs were later picked up by the company owning them and sold in the towns along the river. Before this no rafting of logs down the river had been done, and little was known of long drives; but from this time on log rafts were seen in increasing numbers each year. The camps which were be- 
ing abandoned in central Wisconsin moved northwest into Minnesota. By 1890 the section of country for a hundred miles around Minneapolis was swarming with lumberjacks. Scientific methods of handling lumber and logs came into use. The slow oxen which were used to haul the logs were replaced by draft horses. New mills were built at St. Anthony Falls, and elsewhere, and the whole territory took on a new aspect of industry on a modern scale. The expense of building dams, spillways, and booms was large, and took a great deal of capital. Once the large mills began to run, profits were rapidly realized, and the prosperity of the city grew enormously. Lumber was rafted or shipped down the river or shipped to the eastern markets. There was plenty of it, and it was the one important resource that Minnesota depended upon for its rapid early growth.

Influence of the Wheat Fields. After the lumber industry began to decline, wheat-growing became the important occupation. Even before the lumber industry declined, the vast, fertile wheat fields of the Northwest were being broken up. The industry spread rapidly to the west and north into North Dakota, and Canada, so that by the latter part of the nineteenth century millions of bushels of wheat were being raised every year. This great, fertile area proved to be an excellent region for wheat-growing. The rainfall varies from twenty-seven to thirty inches in Minnesota, and from twentytwo to twenty-five inches in the Dakotas and southern Canada, but the moisture comes in the growing season when it is most needed. The evaporation at this time of the year is moderate, so that even this amount of rain-fall is sufficient for wheat-growing. When the wheat begins to ripen the weather is dry, an excellent condition for the hardening of the grain.

In 1905 South Dakota produced 44,000,000 bushels of wheat, Minnesota $72,000,000$ bushels, and North Dakota 75,000,000 bushels. A small quantity of this wheat moved over the southern railroads to Chicago, and some over the northern route thru the Great Lakes; but by far the greater portion went to Minneapolis to be stored and ground into flour. In 1910 Minnesota alone produced 94,000,000 bushels, and in 1918 the three states of North Dakota, South Dakota, and Minnesota combined produced more than one-fourth of the entire crop of the United States, or a total of over $250,000,000$ bushels.

For a few years elevators could not be built fast enough to take care of the grain. However, in $1920,55,000,000$ bushels of grain could be stored at one time, and the capacity has increased since that date. Chicago is the only grain center in the United States whose terminal capacity approaches the capacity of Minneapolis.

Besides the large elevators in the city of Minneapolis, there are 4300 independent elevators which are operating in a local capacity thruout the Northwest. These smaller companies contract with the farmers for their grain, and send it to Minneapolis to be sold.

The Flour Milling Industry of Minneapolis. As a result of the enormous amounts of grain coming to Minneapolis, the flour-milling industry grew 
rapidly. Today the twenty-three large flour mills can grind 93,000 barrels of flour a day, which amounts to about $\$ 70,000,000$ worth annually. The expense of grinding the wheat in this city is again cheapened by the nearness of the mills to the grain elevators, and to the water power. The transfer of wheat from the elevators to the mills is only a matter of a few hundred feet. As a result of these factors and with the aid of human agencies, Minneapolis has become the largest flour-milling center in the world.

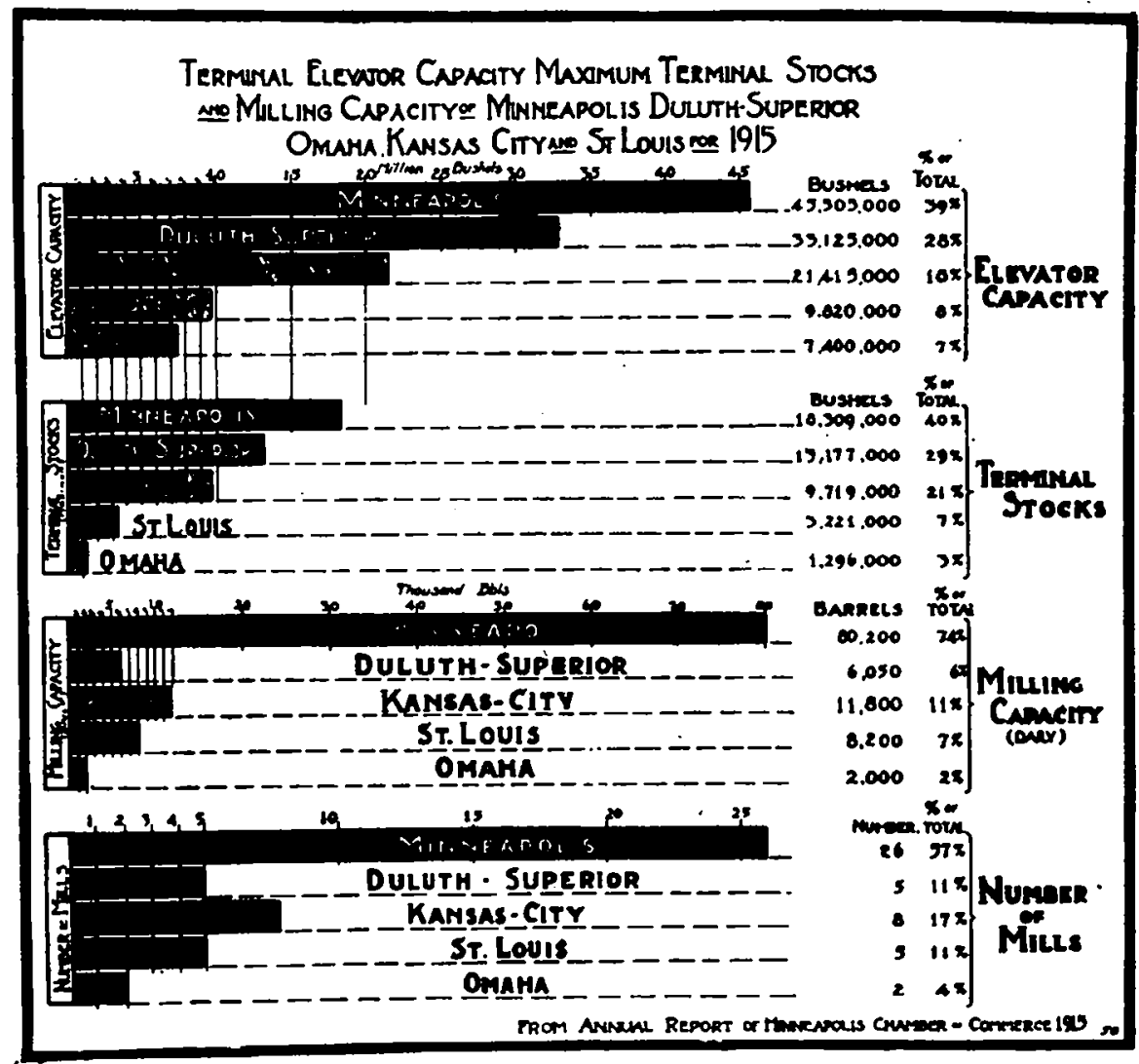

We must attribute the growth of this industry at this particular place to the presence of water power. It is really difficult to say what would have been the development of Minneapolis had it not been for the water power. One author says, "It was the combination of cheap power, the northern pineries on the river above, and the grain fields of the Northwest that determined the location of the city." At least it is safe to say that the wheat and lumber might not have stopped at Minneapolis if it had not been for the cheap power. 
General Manufacturing. The city is favorably located with regard to raw materials, power, and markets. It is the gateway to a region of 400,000 square miles, and of $5,000,000$ inhabitants. This region makes use of a great many kinds of farm machinery and tools. It is a natural result that Minneapolis should handle a large part of this trade. The city is said to be the largest distributing center in the United States for tractors and agricultural implements.

Minneapolis is also located on the edge of the flax-growing region, which ranks as the largest linseed-producing center in the country, its mills having a capacity of 4,800,000 bushels of flax, producing 700,000 barrels of oil, and 300,000 tons of cake per year.

There are many other industries which amount to over $\$ 10,000,000$ each per year.

\section{St. Paul}

The early history of St. Paul varies little from that of Minneapolis. Both cities were settled at about the same time. Father Hennepin, the priestexplorer who first went to Minneapolis in 1679, came to St. Paul in 1680 . During the first few years St. Paul grew faster than its sister city, due to the large trade that came up the river to the foot of the falls.

By 1847 river packets began to run regularly between St. Paul and St. Louis. This had a great influence on the growth of the community, and by $1849 \mathrm{St}$. Paul had a population of 840 . In the next ten years the city was so busy that more than half of the men were engaged in construction work. Small shops sprang up and began to use skins and furs in the manufacture of clothing. Lumber began to come down the river, and more settlers moved in to take advantage of the wealth offered by the forests. St. Paul was located at the northern-most point reached by goods moving up the river, so it became the distributing center for supplies and tools especially those to be used by the lumberman in equipping the lumber camps. In the next ten years St. Paul attained a population of 12,000 , which was doubled in the following decade.

By 1870 both Minneapolis and St. Paul were flourishing cities of more than 25,000 each, with Minneapolis a little in the lead. The fur trade came to St. Paul because of its position on the river at the head of navigation. At the present time sixteen firms are working up 2,000,000 furs every year, making St. Paul one of the leading centers of high grade furs in the United States.

A Dairy Center. As Minneapolis is the wheat center of the Northwest, St. Paul is the dairy center. It is the second largest butter-producing city in the United States. The cream is shipped in from thousands of small stations thruout Minnesota. The many railroad lines coming into St. Paul from every direction make it possible for this cream to be delivered every day, and on the same day that it is separated. In $1919,25,000,000$ pounds of butter were made in this city. 
The Live Stock and Meat Packing Industry. Thousands of cattle, hogs, and sheep are annually shipped to South St. Paul. The packing houses of this part of the city cover 250 acres. The area is flat, and the conditions are favorable for the building of large stockyards and packing houses.

A Manufacturing and Distributing Center. Ever since supplies were brought up the Mississippi River to be sold at the trading post, St. Paul has been a supply station and distributing center for the territory included in the Dakotas, Montana, and Minnesota. The largest shoe-manufacturing establishments of the Northwest are located where the old trading post was.

St. Paul is the hardware center of the Northwest. Thirty acres of floor space are used by the jobbers in assembling machines and tools, to be sent to the western farmers. A few lines of machinery are manufactured in St. Paul, but the greater number are made in the eastern cities and sent to St. Paul for assembling and distributing.

It must be understood that St. Paul is primarily a distributing center and market, and not an industrial city, and so the lack of many large manufacturing plants is not felt as a drawback in the development of the city. However, as the Northwest fills up and the market for manufactured articles and demand for them increases, St. Paul is likely to be the location of large factories.

\section{ConCLUSION}

Twenty-five years ago St. Paul and Minneapolis were two distinct cities, having separate interests and developing under separate conditions. Minneapolis developed because of the water power, and its lumber resources at its door, while St. Paul grew because of the influence of its position as a trading center at the head of navigation on the Mississippi. At the present time, however, a stranger cannot distinguish between the two cities. There are no rural tracts between; the same street cars operate in both cities. In other words the cities really form one city of somewhat more than 600,000 inhabitants.

\section{BIBLIOGRAPHY}

1. E. G. Cheyney. The Development of the Lumber Industry of Minnesota. Journal of Geog., Vol. 14, pp. 189-196.

2. E. Durand, Manufactures in Minnesota, Jour. of Geog., Vol. 14, pp. 218-223.

3. L. L. Everly, Minnesota Cities: St. Paul, Journal of Geog., Vol. 14, pp. 227-229.

4. A. V. Gardner, The Story of the Twin Cities, Bankers Magazine, Vol. 87, pp. 300-319.

5. C. E. Huff, Minnesota Cities: Minneapolis, Journal of Geog., Vol. 14, pp. 223-227.

6. A. W. Johnston, The Physical Geography of Minnesota, Journal of Geog., Vol. 14, pp. 161-165.

7. C. J. Posey, Geographic Influences in the Exploration and Early Development of Minnesota, Journal of Geog., Vol. 14, pp. 214-218.

8. A. M. Washburn, Dairying in Minnesota, Journal of Geog., Vol. 14, pp. 206-211.

9. Bulletin by Minneapolis Civic and Commerce Association.

10. Report by the Commerce Association of St. Paul.

11. United States Census for 1910. 